\title{
A Preliminary Study of Barriers to Bank Financing of Ethnic Chinese Entrepreneurs in the UK
}

\author{
Jane Zhang \\ Edinburgh Napier Business School, Edinburgh Napier University, Scotland, UK \\ Email: ja.zhang@napier.ac.uk
}

Received 18 May 2015; accepted 11 July 2015; published 14 July 2015

\begin{abstract}
Ethnic minority entrepreneurship has been a growing research interest, however, little has been known about financial barriers to start up and run a business venture from the perspectives of UK ethnic Chinese entrepreneurs. The aim of this study is to explore the financial barriers of ethnic Chinese entrepreneurs in starting up and running a business in the UK. Through semi-structured interviews with 12 ethnic Chinese entrepreneurs who run businesses in the UK, this study has preliminarily found: 1) ethnic Chinese businesses in the UK have increasingly faced difficulties to get access to bank finance since the global financial crisis; 2) the difficulties are largely caused by a lack of communication and understanding between the entrepreneurs and financial institutions; 3 ) the traditional perceptions of Chinese businesses have disadvantaged ethnic Chinese entrepreneurs in the UK when they apply for bank credits. This study offers a number of implications. For policy-makers, an understanding of the characteristics of ethnic Chinese businesses and financing barriers to ethnic Chinese in business start-ups and running is important for the development of policy that encourages and supports ethnic Chinese businesses. For banks in the UK to expand their business, there is a need to develop tailored products and services specifically for ethnic Chinese entrepreneurs.
\end{abstract}

\section{Keywords}

Entrepreneurship, Ethnic Minority Entrepreneurship, Ethnic Chinese Business, Financing, SMEs

\section{Introduction}

Across the world, entrepreneurship plays an important part in developing and running businesses, promoting social and economic developments. Entrepreneurship is a social phenomenon with multiple meanings. The literature has interpreted the concept from various perspectives including leadership, marketing, education and background, attitudes towards risk, innovation etc. (e.g., Audretsch, 2012; Crumpton, 2012; Aldrich and Waldinger, 1990) [1]-[3]. Crumpton (2012) [2] considers entrepreneurship as a creative force, involving new ideas and new ways of doing things. Entrepreneur develops, organizes and manages a business venture along with managing of various risks involved in order to achieve a particular objective. Entrepreneurship is widely considered to be an 
engine for creating jobs, economic growth and social adjustment (e.g., Bianchi, 2012) [4].

Ethnic minority entrepreneurship has its unique characteristics different from the mainstream of entrepreneurship. Ethnic minority entrepreneurs are mainly migrants and second or third generations from ethnic minorities. They have many disadvantages in comparison with natives in terms of language, education, social and cultural acceptance, access to supports and skills, and integration with the mainstream of a society. The previous literature has revealed that ethnic minority businesses face many new difficulties (e.g., Assudani, 2009; Deakins et al., 2003; Fadahunsi et al., 2000) [5]-[7]. For many ethnic minority entrepreneurs, there is a lack of formal qualification and basic language skills. Most of them are willing to take risks by setting up a new business associated with their native sources of suppliers or customers. In many cases, to those people who do not have a chance for gaining formal employment, self-employment therefore acts as an alternative. Among many ethnic minority entrepreneurs, their business ventures intend to be micro and small-sized, concentrating in commerce and catering sectors, lacking of technology and professionalism. The unique problems faced by migrant/ethnic entrepreneurs include access to finance and support services, language barriers, limited business, management and marketing skills, over-concentrated in low entry threshold activities where the scope for breakouts or diversification into mainstream markets is limited.

Ma et al. (2013, p. 47) [8] document that "the past research on ethnic entrepreneurship has largely focused on the change in social and economic status of ethnic entrepreneurs as well as the socioeconomic factors that may affect ethnic entrepreneurial activities, reflecting the struggling process for ethnic and immigrant entrepreneurs as an underrepresented group to seek for survival in the new lands". However, the review of the literature reveals that from a UK perspective few data exist on the Chinese business community (Chaudhry and Crick, 2004) [9]. This study aims to make a contribution by investigating ethnic Chinese business access to bank financing in the UK.

\section{Literature Review}

\subsection{Ethnic Entrepreneurs and Ethnic Chinese Entrepreneurs in the UK}

Ethnic entrepreneurs are usually referred to as simultaneously owners and managers of their own businesses, whose group members are tied to a common cultural heritage or origin (Curran and Blackburn, 1993) [10]. According to U.S. Department of Commerce (1997) [11], ethnic entrepreneur means "business ownership by any individual who is not of the majority population". Cooney (2005) [12] defines ethnic entrepreneurship by extending the minority beyond the race origins. He considers ethnic entrepreneurs not just ethnic; they are also any group of entrepreneurs who are considered to be outside mainstream society. Ethnic entrepreneurs are intrinsically intertwined in particular social structures and network in which individual behavior, social relations, and business transactions are constrained (Zhou, 2004; Aldrich and Waldinger, 1990) [3] [13].

In the UK, the five largest groups of 'ethnic minority entrepreneurs' are African-Caribbean, Indian, Pakistani, Bangladeshi and Chinese (Centre for Enterprise and Economic Development Research, 2001) [14]. Ethnic Chinese entrepreneurs in the UK face many barriers to starting a new business. In addition to the barriers faced by native entrepreneurs, they also face additional barriers subject to their personal circumstances and cultural background, including, for example, lack of confidence, personal problems, lack of skills, start-up logistics difficulties, financial needs and time constraints, and lack of access to information and service support (Chaudhry and Crick, 2004; Siu et al., 2003) [9] [15]. Ethnic Chinese businesses in the UK are mainly in the sectors of catering, foods, small-scale commerce, and tours and travels. A large proportion of Chinese ethnic businessmen in the UK are Cantonese-speaking Chinese (Chaudhry and Crick, 2004; Siu et al., 2003) [9] [15]. Originally they came from Hong Kong and South East of China. There is a tendency for second-generation ethnic Chinese entrepreneurs to set up businesses in different sectors to those of their parent generation. They have moved away from traditional restaurant and takeaways with long hours and low pay into professionals and services (such as Chinese medicine and health care, supermarkets, IT, property management and development, and financial investment), which offer greater prestige and higher potential returns. Chinese entrepreneurs are generally represented as more strongly rooted in family resources than even South Asians (Ram and Jones, 2008) [16].

\subsection{Ethnic Chinese Minority Business and Finance}

Access to finance has been cited as one of the most significant barriers facing ethnic minority businesses (Carter 
et al., 2015; Bates, 2011) [17] [18]. There was evidence that ethnic minority business (particularly black-owned businesses) do face discrimination in interest rates when they borrow from finance companies and businesses in the US (Blanchard et al., 2008; Cavalluzzo and Wolken 2005) [19] [20]. Similar evidence of discrimination was also found in the UK (Fraser, 2009) [21]. In the UK, most ethnic Chinese businesses relied on personal savings to fund the business start-up (Chaudhry and Crick, 2004) [9]. Typically, savings had arisen from work in other catering businesses (such as takeaways and restaurants) prior to starting their own business venture. Ethnic Chinese business have also utilized community ties (e.g., borrowing from other Chinese and particularly fellow people from the same hometown). The use of community ties could help avoid interest rates charged by commercial institutions such as banks (Chaudhry and Crick, 2004) [9]. As revealed by Chaudhry and Crick (2004) [9], the Chinese community network was widely utilized among Chinese entrepreneurs to overcome the perceived barrier of discrimination and high interest from the banking institutions at the start-up phase.

\section{Research Methodology}

Research methodology is usually regarded as a system of definite rules and procedures upon which a piece of research is based and against which claims for knowledge. Methodology provides rules and guidance for researchers and readers to communicate, and it sets up rules for logical and valid reasoning, which constructs the basis for researchers to carry out the research and guide the research activity. Methodology also provides conventions for inter-subjectivity, specifically the ability to share understanding and knowledge and explicates the accepted criteria for pragmatic "truth" and "objectivity", and it offers the methods and techniques for validation of research findings.

\subsection{Research Design}

In this study the researcher takes a more constructivist point of view by recognizing that ethnic Chinese entrepreneurs in the UK are influenced by the changing social and business environments. This study is based on the belief that social phenomena and the environments of ethnic Chinese entrepreneurs vary across different time periods and among the changes of policies and markets. This study adopts a qualitative research through interviews. The choice of this method is due to the difficulties of getting accurate data which is largely absent or not easily available. This study adopts inductive and qualitative research approach because the research objective of this study is to identify the barriers to gaining access to bank financing from the ethnic Chinese entrepreneur perspectives. For reasoning it is a process of from specific observations to broader generalizations and theories, which is a typical inductive reasoning (i.e., a researcher begins with specific observations and measures, begins to detect patterns and regularities, formulates some tentative hypotheses that the researcher can explore, and finally ends up developing some general conclusions or theories). Interviews as a technique for collecting data have a number of advantages compared with other methods such as interviews are more reliable and objective than the other social surveys (Edmondson and McManus, 2007; Curran and Blackburn, 1991) [10] [22]. For the purpose of this study, the interviewees are those who are presently running a business in the UK with ethnic Chinese minority background. Boyce and Palena (2006) [23] stress in-depth interviewing is a qualitative research technique which conducts individual interviews with a small number of participants and their perspectives are utilized to research a specific idea or situation. The interviews were carried out as the semi-structured interviews, which allow new ideas to be brought up during the interviews. In this study, each participant was asked same questions, but left time space for further questions when appropriate, subject to their responses to individual questions.

This study aims to identify the barriers faced by ethnic Chinese entrepreneurs in accessing to bank financing. The core of this research is to gain the views of ethnic Chinese entrepreneurs in the UK on the difficulties and actual barriers in accessing to bank credits in setting up a new business venture and the development of ethnic entrepreneurship.

\subsection{Interviews}

12 Interviews were conducted in January and March 2015 in a semi-structured format with ethnic Chinese entrepreneurs who are currently small business owners in London and Edinburgh. Each interview took about one hour and interviews were conducted in the premise of the interviewees. The interviews were conducted in Man- 
darin Chinese due to language barriers of some ethnic Chinese entrepreneurs. The interview questions were developed prior to the conduct of interviews. The questions focused on the research objectives and the key issues that the researcher was interested. Main interview questions consist of factors influencing decision-making of borrowing from banks and barriers to accessing bank finance.

\section{Interview Results and Findings}

The interviews focus on the experience of these individuals in accessing bank finance and their views concerning the barriers for ethnic minority businesses to obtain supports from the banking industry in the UK. The interviews cover three parts. The first part is an introduction. The researcher first introduced herself and explained the purpose and process of the interviews. The researcher ensured the confidentiality of the information and anonymity of interviewees in the research. In the first part of interviews, there were three very general questions to open up conversations, including: How long have you been living in the UK? Where did you come from? How long have you been running this business? Most the interviewees have lived in the UK for more than 15 years and originally they were mainly from Hong Kong, Guangdong, Fujian and Zhejiang (Southern East of China) (similar to those explained in Li, 2005 and Siu et al., 2003) [15] [24].

The main questions were related to their decisions to borrow from banks and barriers to gain access to finance from banks. Most interviews mentioned short-term cash flow difficulties was one of the main reasons for them to consider banks as an 'easy' source. Most ethnic Chinese businesses used their own money or money from their family and relatives to start up a business venture. However, when a business does not do well sometimes resulting in financial difficulties, they intend to get financing from banks, rather than asking again for the family or relatives to support. The other factor to use bank financing is tax advantage as interest on bank borrowing can be used to against income taxes. This was largely suggested by their accountants.

With regard to the barriers to start a new business venture in the UK for ethnic minority Chinese, in addition to language and cultural barriers and race discrimination, most interviewees considered lack of finance, support, information, experience and connections with the mainstream of business communities as the main problems. Especially since the global financial crisis, it has been more difficult for ethnic Chinese businesses to borrow from banks. On the one hand, the amount of credits available in the banking sector has been reduced resulting in less lending to SMEs including ethnic minority businesses as a whole. On the other hand, there have been difficulties in communication and understanding between ethnic Chinese entrepreneurs and banks. As commented by several interviewees, bank managers do not understand many business proposals raised by ethnic minority Chinese and they have limited knowledge of the rapid development of the Chinese economy as some new business proposals are connected with businesses in China. In developing new business proposals, ethnic Chinese entrepreneurs (particularly the second and third generations) place much importance on niche markets, specialized fields of demand where new ventures can enjoy a competitive edge over non-minority firms. Because of niche and specialized nature, it is not easy to be understood when they apply for a loan from banks.

One interviewee gave an example: "[ []$]$ wo years ago I had a new business proposal trying to set up a trading business in London to sell energy-saving products produced in China. That product was so popular in China and I knew it could have a big market in the UK. When I produced a business plan and cash flow forecast to my bank manager asking for loans, the bank manager did not believe my figures. He had no clue that manufacturing cost in China was so low. He just could not understand the market and the business at all. My application for loan was rejected".

Another interviewee stated: "[w] hen you talked to bank managers about your business proposal, they always thought your proposal would be linked with Chinese foods, takeaway or restaurant. They assume you would make good money and would have full support from family. You do not need finance borrowing from banks. If you come to a bank asking for loan, they presume your business is going to fail. The perception about ethnic Chinese business gives us disadvantages in accessing bank finance. I think it will take a while to change this perception".

In terms of business finance, most ethnic people rely on family support and support from social networks (such as friends, and other Chinese who came from the same place). Also, for many ethnic Chinese, they receive a lot of help from local church they attend. Helping each other seems to be a norm for many ethnic Chinese entrepreneurs in starting up and running a business. This is probably due to trust and cultural similarity and people can understand each other. This is related to the importance of social networking in entrepreneurship as identi- 
fied in the prior literature (e.g., Witt, 2004; Dodd and Patra, 2002) [25] [26]. Some comments by interviewees illustrate these points. "People do not start businesses in a vacuum and families are always the starting point to consult. In my view, families play an important role in financing business. For ethnic minority Chinese, families are the foundation of any new business venture as families provide finance and all other suppliers" (Interviewee B).

The interviews indicate there is a lack of tailored support from commercial banks to ethnic Chinese entrepreneurs in their business start-ups. Although there are plenty of supports and government programs for SMEs and start-ups, these are very general, mainly for local white entrepreneurs. Finance and bank supports are limited to general entrepreneurs. Little tailored support has been provided to ethnic Chinese entrepreneurs. The findings of this study are generally consistent with those of Smallbone et al. (2005) [27] who consider more broadly ethnic minority businesses in the UK. Ethnic Chinese entrepreneurs face the barrier of accessing to formal finance from banks and capital markets. Most ethnic Chinese businesses lack creditworthiness, so they have trouble securing funds for their business activities. In the views of many bank lending managers, ethnic Chinese businesses are often regarded as insecure and costly businesses to deal with because they lack required collateral and have the capacity to absorb only small amount of funds from financial institutions, plus it is more likely to cause some confusion and take more time in explaining and negotiating terms due to language problems. Therefore, they are basically rationed out in their access to credit and bank finance because of high intermediation costs, including the cost of monitoring and enforcement of loan contracts.

\section{Conclusion}

Although the importance of ethnic minority entrepreneurship has been widely recognized, the literature has paid little attention to ethnic Chinese entrepreneurship in the UK. This study intends to fill in this research gap by exploring the barriers to accessing bank financing of ethnic Chinese entrepreneurship in starting up and running a business venture. Based on 12 interviews with ethnic Chinese entrepreneurs in London and Edinburgh, this study finds: 1) ethnic Chinese businesses in the UK have increasingly faced difficulties to get access to bank credits since the global financial crisis; 2) the difficulties are largely caused by a lack of communication and understanding between the entrepreneurs and financial institutions; 3) traditional perceptions of Chinese businesses have disadvantaged ethnic Chinese entrepreneurs in the UK when they apply for loans from commercial banks. This study offers a number of implications. For policy-makers, an understanding of the characteristics of ethnic Chinese businesses and financing barriers to ethnic Chinese in business start-ups and running is important for the development of policy that encourages and supports ethnic Chinese businesses. For banks in the UK to expand their business, there is a need to develop tailored products and services specifically for ethnic Chinese entrepreneurs.

\section{References}

[1] Audretsch, D. (2012) Entrepreneurship Research. Management Decision, 50, 755-764. http://dx.doi.org/10.1108/00251741211227384

[2] Crumpton, A.M. (2012) Innovation and Entrepreneurship. The Bottom Line, 25, 98-101. http://dx.doi.org/10.1108/08880451211276539

[3] Aldrich, H.E. and Waldinger, R. (1990) Ethnicity and Entrepreneurship. Annual Review of Sociology, 16, 111-135. http://dx.doi.org/10.1146/annurev.so.16.080190.000551

[4] Bianchi, M. (2012) Financial Development, Entrepreneurship, and Job Satisfaction. The Review of Economics and Statistics, 94, 273-286. http://dx.doi.org/10.1162/REST a 00156

[5] Assudani, R.H. (2009) Ethnic Entrepreneurship: The Distinct Role of Ties. Journal of Small Business and Entrepreneurship, 22, 197-206. http://dx.doi.org/10.1080/08276331.2009.10593450

[6] Deakins, D., Ram, M. and Smallbone, D. (2003) Addressing the Business Support Needs of Ethnic Minority Firms in the United Kingdom. Environment and Planning C: Government and Policy, 21, 843-859. http://dx.doi.org/10.1068/c0305

[7] Fadahunsi, A., Smallbone, D. and Supri, S. (2000) Networking and Ethnic Minority Enterprise Development: Insights from a North London Study. Journal of Small Business and Enterprise Development, 7, 28-40. http://dx.doi.org/10.1108/eum0000000006842

[8] Ma, Z., Zhao, S., Wang, T. and Lee, Y. (2013) An Overview of Contemporary Ethnic Entrepreneurship Studies: 
Themes and Relationships. International Journal of Entrepreneurial Behaviour \& Research, 19, 32-52. http://dx.doi.org/10.1108/13552551311299242

[9] Chaudhry, S. and Crick, D. (2004) The Business Practices of Small Chinese Restaurants in the UK: An Exploratory Investigation. Strategy Change, 13, 37-49. http://dx.doi.org/10.1002/jsc.655

[10] Curran, J. and Blackburn, R. (1993) Ethnic Enterprise and the High Street Bank, Kingston Business School, Kingston University, London.

[11] U.S. Department of Commerce (1997) The State of Small Business: A Report of the President.

[12] Cooney, T.M. (2005) What Is an Entrepreneurial Team? International Small Business Journal, 23, 226-235. http://dx.doi.org/10.1177/0266242605052131

[13] Zhou, M. (2004) Revisiting Ethnic Entrepreneurship: Convergences, Controversies, and Conceptual Advancements. International Migration Review, 38, 1040-1074. http://dx.doi.org/10.1111/j.1747-7379.2004.tb00228.x

[14] Centre for Enterprise and Economic Development Research (2001) http://www.sbs.gov.uk/content/pdf/embf/BBA Access to Finance Research.pdf

[15] Siu, W.-S., Zhu, Y. and Kirby, D.A. (2003) The Interplay of Environment and Culture in Small Firm Marketing: A Comparative Study of the Marketing Practices of Chinese Small Firms in Hong Kong and The UK. Journal of Small Business and Enterprise Development, 10, 25-39. http://dx.doi.org/10.1108/14626000310461196

[16] Ram, M. and Jones, T. (2008) Ethnic Minorities in Business. 2nd Edition, Small Business Research Trust, Milton Keynes.

[17] Carter, S., Mwaura, S., Ram, M., Trehan, K. and Jones, J. (2015) Barriers to Ethnic Minority and Women's Enterprise: Existing Evidence, Policy Tensions and Unsettled Questions. International Small Business Journal, 33, 49-69. http://dx.doi.org/10.1177/0266242614556823

[18] Bates, T. (2011) Minority Entrepreneurship. Foundations and Trends in Entrepreneurship, 7, 151-311. http://dx.doi.org/10.1561/0300000036

[19] Blanchard, L., Yinger, J. and Zhao, B. (2008) Do Lenders Discriminate Against Minority and Women Entrepreneurs? Journal of Urban Economics, 63, 467-497. http://dx.doi.org/10.1016/j.jue.2007.03.001

[20] Cavalluzzo, K. and Wolken, J. (2005) Small Business Loan Turndowns, Personal Wealth and Discrimination. Journal of Business, 78, 2153-2178. http://dx.doi.org/10.1086/497045

[21] Fraser, S. (2009) Is There Ethnic Discrimination in the UK Market for Small Business Credit? International Small Business Journal, 27, 583-607. http://dx.doi.org/10.1177/0266242609338756

[22] Edmondson, A. and McManus, S. (2007) Methodological Fit in Management Field Research. Academy of Management Review, 32, 1155-1179. http://dx.doi.org/10.5465/AMR.2007.26586086

[23] Boyce, C. and Palena, N. (2006) Conducting In-Depth Interviews: A Guide for Designing and Conducting In-Depth Interviews for Evaluation Input. Pathfinder International Tool Series: Monitoring and Evaluation 2.

[24] Li, P.S. (2005) The Rise and Fall of Chinese Immigration to Canada: Newcomers from Hong Kong Special Administrative Region of China and Mainland China, 1980-2002. International Migration, 43, 9-34. http://dx.doi.org/10.1111/j.1468-2435.2005.00324.x

[25] Witt, P. (2004) Entrepreneurs' Networks and the Success of Start-Ups. Entrepreneurship and Regional Development, 16, 391-412. http://dx.doi.org/10.1080/0898562042000188423

[26] Dodd, S.D. and Patra, E. (2002) National Differences in Entrepreneurial Networking. Entrepreneurship and Regional Development, 14, 117-134. http://dx.doi.org/10.1080/08985620110111304

[27] Smallbone, D., Bertotti, M. and Ekanem, I. (2005) Diversification in Ethnic Minority Business: The Case of Asians in London's Creative Industries. Journal of Small Business and Enterprise Development, 12, 41-56. http://dx.doi.org/10.1108/14626000510579635 